\title{
Effect of Temperature and Age of Concrete on Strength - Porosity Relation
}

\author{
T. Zadražil, F. Vodák, O. Kapičková
}

The compressive strengths of unsealed samples of concrete at the age of 180 days and have been measured at temperatures $20^{\circ} \mathrm{C}, 300{ }^{\circ} \mathrm{C}$, $600^{\circ} \mathrm{C}$ and $900^{\circ} \mathrm{C}$. All of tests were performed for cold material. We compared our results with those obtained in [10] for the same type of concrete (age 28, resp. 90 days and measured at temperature ranging from $20^{\circ} \mathrm{C}$ to $280^{\circ} \mathrm{C}$ ). Dependencies of compressive strength and porosity were correlated together and compared for the samples of age 28, 90 and 180 days. Behaviour of concrete of the age 90 , resp. 180 days confirms generally accepted hypothesis that with increasing porosity strength of the concrete decreases. It has to be stressed out, howerer, that concrete samples of the age 28 days exhibit totally opposite dependency.

Keywords: compressive strength, temperature dependency, porosity.

\section{Introduction}

As known from experimental studies of concrete behaviour at room temperature, there is a close correspondence between compressive strength $S$ and its porosity $P$. Commonly this dependence is decreasing function, i.e. strength $S$ decreases with porosity $P$. There are many attempts to express the relation $S=S(P)$ in an analytical form. It has to be pointed out, however, that such expressions (as, for example, Bal'shin relation, Ryshkewitch expression, Schiller law, Hasselman formula - for details see, e.g., [1]) have been mostly derived for different type of materials.

The present paper is based on the assumption that changes in porosity $P$ are the main factor effecting changes in compressive strength $S$ of hardened cement pastes and concrete (see, e.g., [2]). The hypothesis is generally accepted, howerer, some doubts exist [3,4]. Moreover, practically in all articles cited above the dependence $S=S(P)$ porosity was modified by a change of $w / c$ ratio. In the present paper all specimens were prepared at the some $w / c$ coefficient for all tested samples and the porosity varied due to heat treatment at different temperature levels. It is therefore interesting to the dependence of compressive strength $S$ on porosity $P$ in that case and check, if $S=S(P)$ is at least qualitatively the same as for the porosity modified by $w / c$ ratio.

\section{Experiment}

\subsection{Composition of concrete}

The tested specimens for the whole experimental program were made from the concrete mixture, the composition of which is given in Table 1. Composition corresponds to the concrete composition applied in real structures (in the containment of NPP Temelin). The mineral composition of cement in percentage by weight can be found in [5]. The mineral composition of cement in percent per volume is given in Table 2. Applied starting material is Portland cement with a small amount of fly ash and traces of slag. The clinker used for its production was burnt on the optimum content of free $\mathrm{CaO}$ and has a high fraction of alite and $\mathrm{C}_{4} \mathrm{AF}$ prevailing over $\mathrm{C}_{3} \mathrm{~A}$ in it. An average size of crystals ranges between $0.025-0.030 \mathrm{~mm}$ and a size of belite grains is about $0.20 \mathrm{~mm}$ in average.
Table 1: Composition of $1 \mathrm{~m}^{3}$ of concrete mixtures Temelín

\begin{tabular}{|c|c|}
\hline Cement & $499 \mathrm{~kg}$ \\
\hline Water & $215 \mathrm{~kg}$ \\
\hline $\begin{array}{c}\text { Plasticizer } \\
\text { (Ligoplast SF) }\end{array}$ & $4.9 \mathrm{~kg}$ \\
\hline & $710 \mathrm{~kg}(0-4 \mathrm{~mm})$ \\
& $460 \mathrm{~kg}(8-16 \mathrm{~mm})$ \\
Aggregates & $530 \mathrm{~kg}(16-22 \mathrm{~mm})$ \\
\hline
\end{tabular}

Table 2: Quantitative composition of cements in $\%$ by volume

\begin{tabular}{|l|c|}
\hline \multicolumn{2}{|c|}{ CEM I 42.5 Mokrá } \\
\hline Phase clinker composition \\
\hline $\mathrm{C}_{3} \mathrm{~S}$ & 70.0 \\
\hline $\mathrm{C}_{2} \mathrm{~S}$ & 11.4 \\
\hline $\mathrm{C}_{3} \mathrm{~A}$ & 7.9 \\
\hline $\mathrm{C}_{4} \mathrm{AF}$ & 9.7 \\
\hline $\mathrm{C}_{\text {free }}$ & 1.0 \\
\hline Total & 100.0 \\
\hline Fraction of components in cement \\
\hline Clinker & 93.3 \\
\hline Gypsum & 4.7 \\
\hline Fly ash & 1.8 \\
\hline Slag & 0.2 \\
\hline Total & 100.0 \\
\hline
\end{tabular}

\subsection{Manufacturing of samples}

Mixing of concrete mixtures was carried out in the laboratory mixer with the forced circulation. The careful procedure of loading the ingredients to the mixer and kept time schedule of mixing guaranteed the homogeneous concrete mixture 
of constant quality in all batches. The tested specimens for the experimental program were manufactured in two relays. Attention was paid to the specimens curing. First, the specimens were covered with a polyethylene foil that restrained the leakage of excessive water from the surface bed of the tested body. Then, approximately six hours after the manufacturing ended, the samples including the forms were covered with a damp fabric and then they were recovered with a polyethylene foil. The basic specimen of the experimental program was $0.1 / 0.1 / 0.4 \mathrm{~m}$ beam.

\subsection{Heating of specimens}

The concrete samples were placed in the high-temperature furnace BVD 100/KY (temperature range up to $1250{ }^{\circ} \mathrm{C}$ ) with the programmable heating and cooling regulator. Temperature increases $100^{\circ} \mathrm{C}$ each 15 minutes during the heating up to final temperature $300{ }^{\circ} \mathrm{C}, 600^{\circ} \mathrm{C}, 900{ }^{\circ} \mathrm{C}$, respectively. Samples were exposed to high temperatures for 2 hours. Cooling rate was $100^{\circ} \mathrm{C}$ per 30 minutes.

Duration of exposure at elevated temperatures ( 2 hours) practically guarantees that the samples are heated uniformly within whole specimen volume. This time period was estimated from solution of heat conductivity equation. Appropriate input parameters (in particular, thermal conductivity coefficient, resp. specific heat capacity and its dependency on temperature) were taken from [6].

\subsection{Tests of concrete mechanical properties}

The compressive strength was determined on the fragments of the beams of the original dimensions $0.1 / 0.1 / 0.4 \mathrm{~m}$ after the fracture toughness measurement referred in the previous paper [11]. All of the tests were performed according to the method of the Czech National Standard CSN 731318. The measurements of the compressive strength were performed on 6 specimens for each temperature level.

\subsection{Tests of concrete porosity properties}

The small fragments of the beam after strength tests were utilized to determine the concrete texture. Samples were dried at temperature $105^{\circ} \mathrm{C}$ for 4 hours before measurement. The porosity of hardened cement paste has been measured by the method of mercury porosimetry using high-pressure porosimeter Micrometrics Auto-Pore 9200 (with pressure range up to $400 \mathrm{MPa}$ ). The porosity was measured on 6 specimens for each temperature level.

\section{Results and discussion}

Dependence of compressive strength on the temperature level of heating is shown in Fig. 1. Furthermore, the ratio of strength value after cooling of the sample and its original strength value (determined by indoor temperature before heat pretreatment) is generally referred to be "residual stregth ratio" [7]. These results are depicted in Fig. 2. The changes of the porosity with temperature of heating are presented in Fig. 3. (Each point of these curves corresponds to the average of six values measured on different specimens heated at the same temperature level). According to these measurements representative values of strength $(S)$ and porosity $(P)$ for a given temperature were obtained and successively functional dependency $S=S(P)$ was established, see Fig. 4. The analogical results for concrete at the age of 28 days

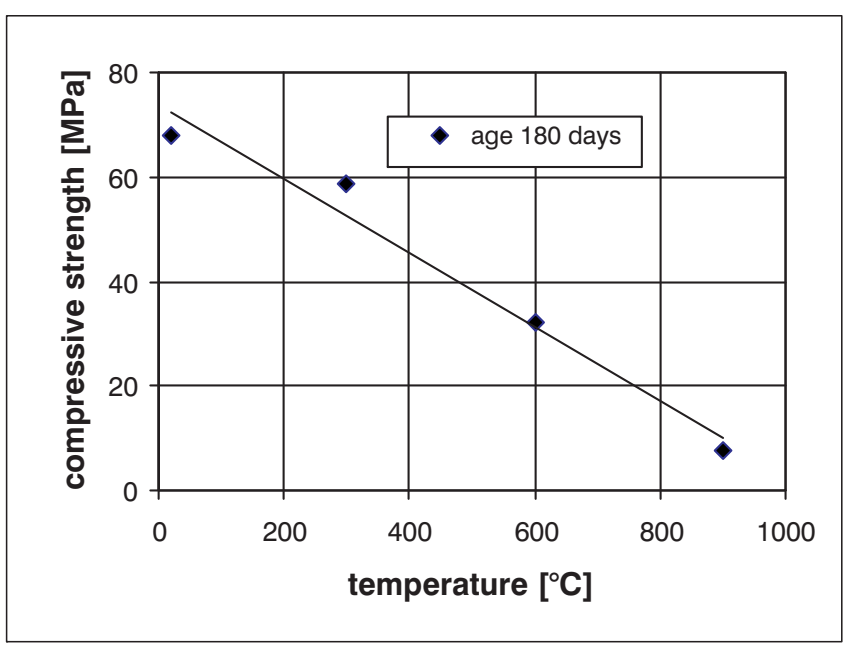

Fig. 1: Effect of temperature on compressive strength for concrete of age 180 days

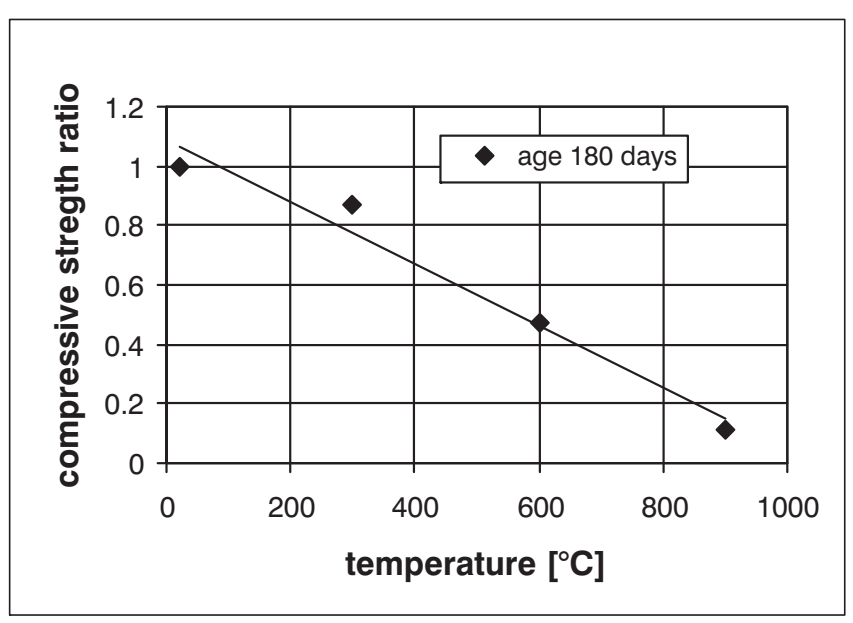

Fig. 2: Effect of temperature on compressive strength ratio for concrete of age 180 days

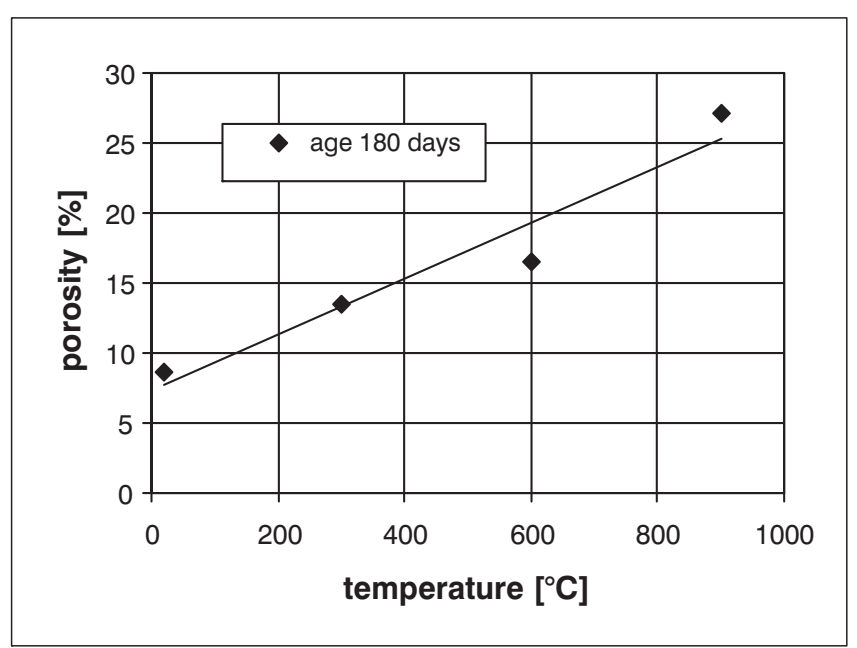

Fig. 3: Effect of temperature on porosity for concrete of age 180 days 


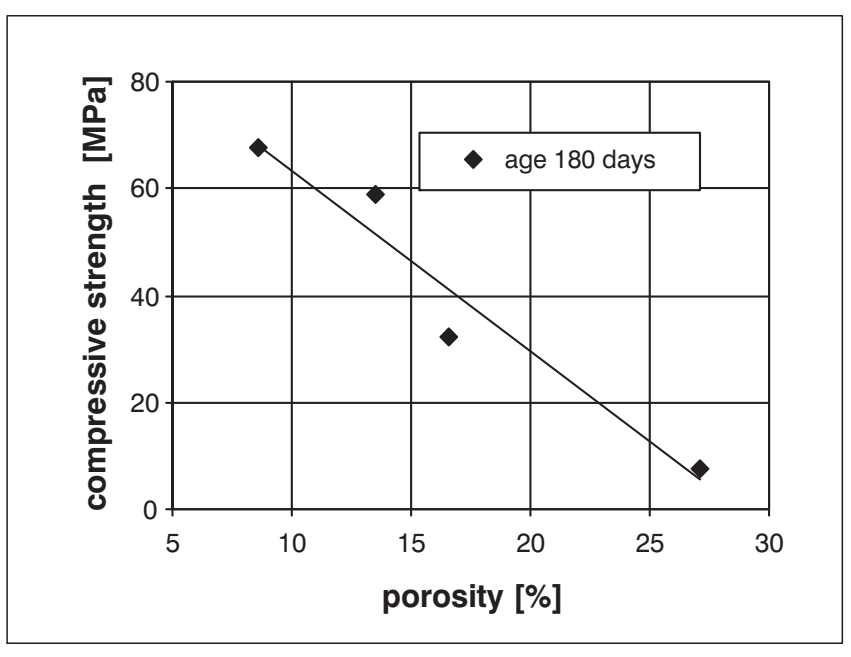

Fig. 4: Dependence of compressive strength on porosity for concrete of age 180 days

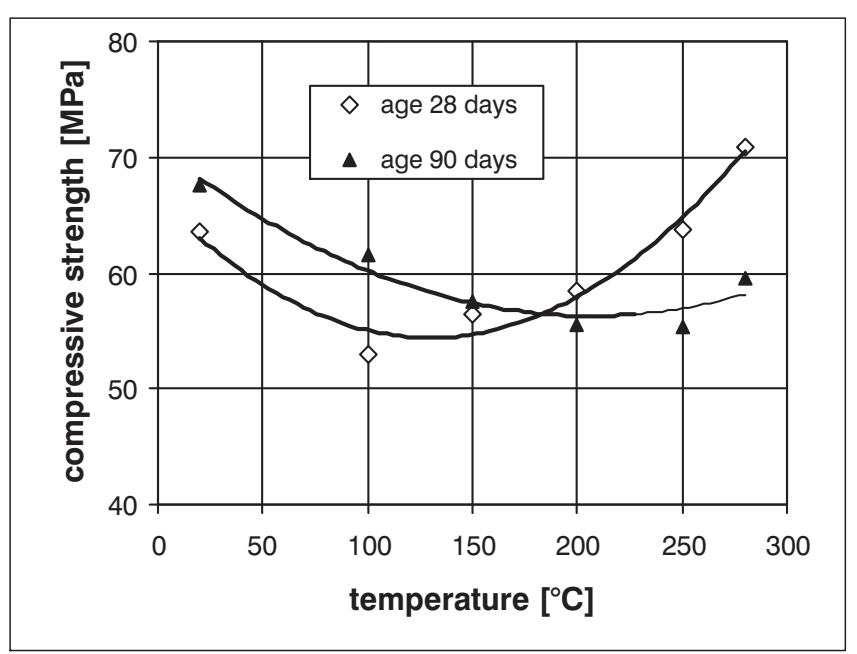

Fig. 5: Effect of temperature on compressive strength for concrete of age 28 and 90 days

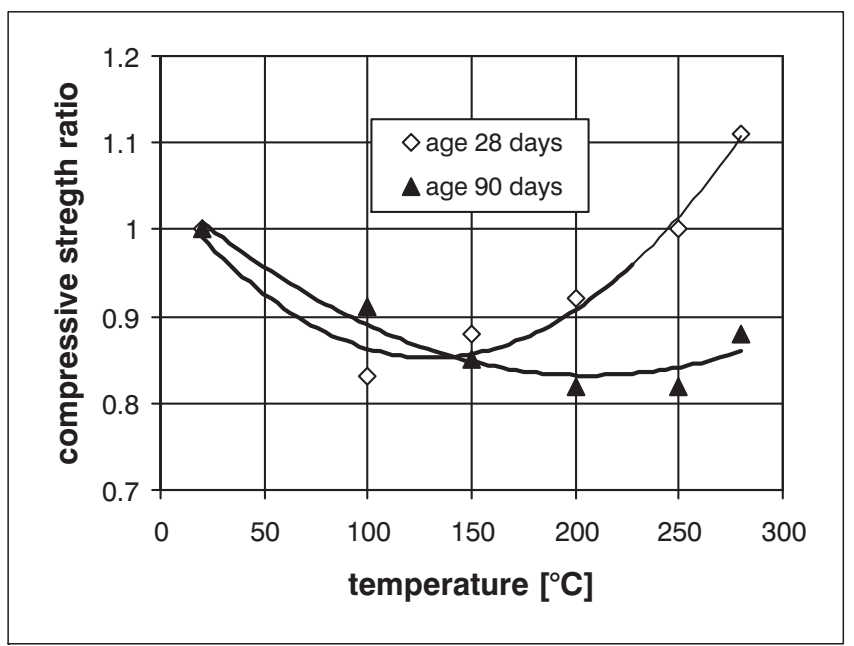

Fig. 6: Effect of temperature on compressive strength ratio for concrete of age 28 and 90 days

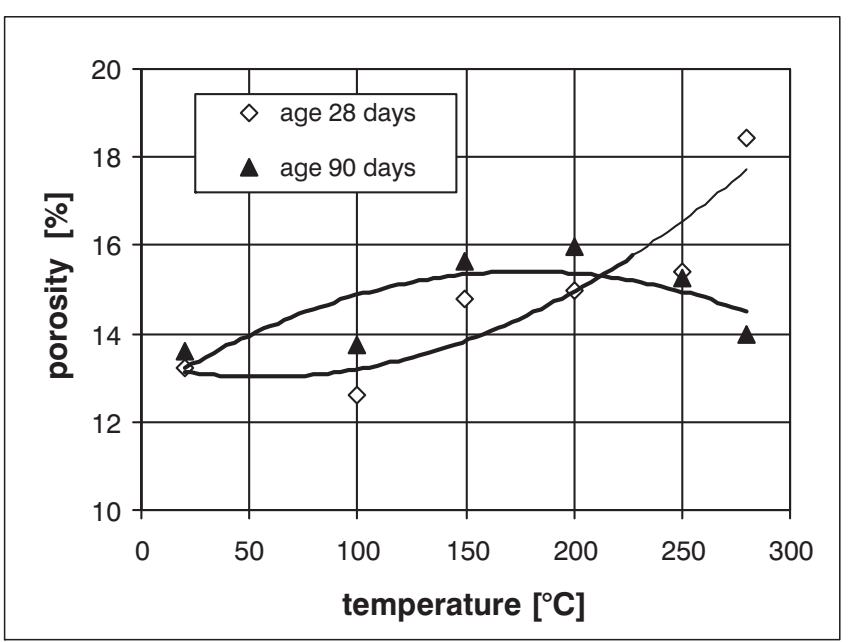

Fig. 7: Effect of temperature on porosity for concrete of age 28 and 90 days

and 90 days treated in the temperature range $\left\langle 20^{\circ} \mathrm{C}-280^{\circ} \mathrm{C}\right\rangle$ are in Figs. 5-9 [10]. These dependences $S=S(P)$ were compared for different ages of concrete samples (Figs. 4, 8, 9). Behaviour of concrete samples aged 90 and 180 days (Figs. 4, 9) confirms decreasing compressive strength with the increasing porosity. Samples of the age 28 days behave quite oppositely, the compressive strength increases with the increasing porosity (Fig. 8).

Practically in all published papers dependence $S=S(P)$ is studied at constant (room) temperature and specimens porosity is modified only by change of $w / c$ ratio. Our atypical dependence for samples aged 28 days is due to temperature effect. Usually three competitive factors result from the analysis of temperature influence on properties of concrete:

a) Drying in the temperature range $\left\langle 100{ }^{\circ} \mathrm{C}-200{ }^{\circ} \mathrm{C}\right\rangle$ increases the strength [7].

b) The increasing content of hydration products occurring in the temperature range $100{ }^{\circ} \mathrm{C}$ to $300{ }^{\circ} \mathrm{C}$ (note that the bound water starts to be released at $180{ }^{\circ} \mathrm{C}$ [9]) leads to an increase of concrete strenght [8]. A probable reason is larger mobility of water molekules in gaseous phase (as compared with their mobility in liquids).

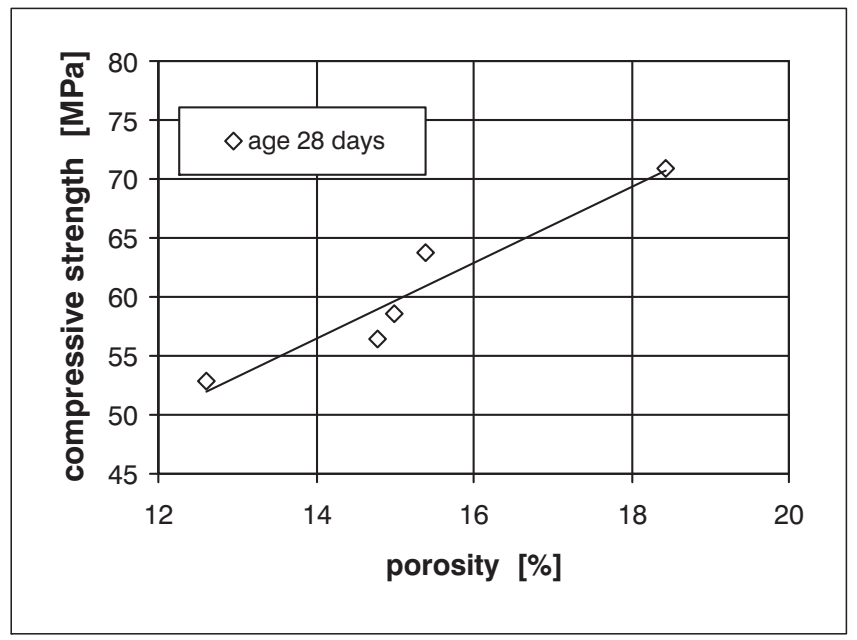

Fig. 8: Dependence of compressive strength on porosity for concrete of age 28 days 


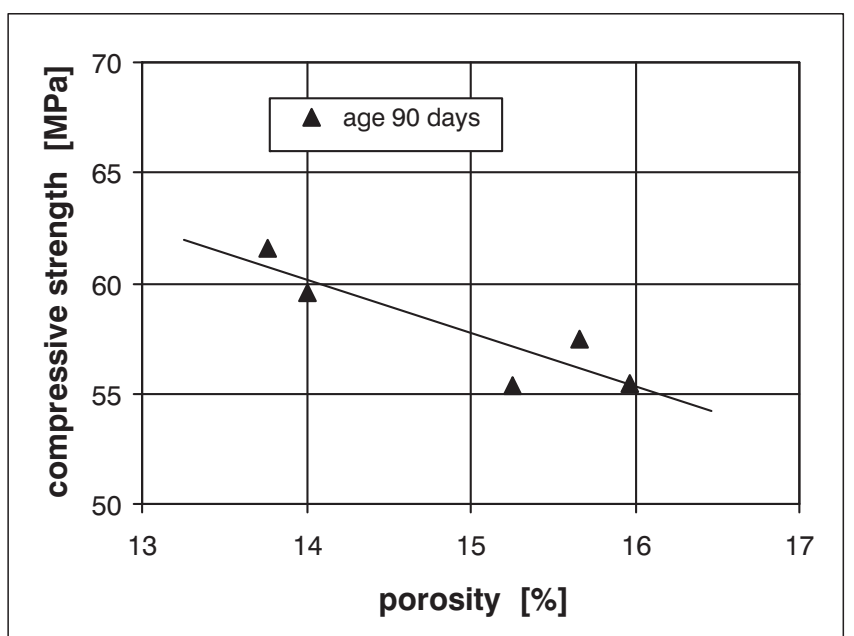

Fig. 9: Dependence of compressive strength on porosity for concrete of age 90 days

c) Microcracking due mainly to thermal incompatibility of the hardened cement paste and aggregate which increases porosity and decreases strength [7]. This process takes place throughout whole temperature interval.

From presented measurements may be deduced that resulting balance of these three influences essentially depends on the age of concrete. Increasing content of hydration products plays dominant role, especially for concrete at the age of 28 days (with relatively large volume of unhydrated cement) due to intensifying hydration with temperature (between $\left.\left\langle 100{ }^{\circ} \mathrm{C}-300{ }^{\circ} \mathrm{C}\right\rangle\right)$. This process causes similar behaviour of strength as certain curing treatments (so-called steam curing). These facts result in extraordinary dependence of strength on porosity (Fig. 8), which behaves as increasing function, contrary to original hypothesis. On the other hand, hydration processes are practically terminated in concretes at the age of 90 days and the functional dependence $S=S(P)$ (Fig. 9) corresponds to initial hypothesis, since the major role is now played by microcracking. Additional „minihydration“ is caused mostly by water molecules of relatively high kinetic energies released at temperatures above $250{ }^{\circ} \mathrm{C}$. This phenomenon, which leads to low increasing of the strength and decreasing of the porosity (see Figs. 5 and 7), is again in good agreement with initial hypothesis. The results for the concrete at the age 180 days are quite problemless. The function $S=S(T)$ decreases, the function $P=P(T)$ increases and the dependency $S=S(P)$ is the decreasing function. We may suppose that all significant hydration processes are finished at this age and changes of porosity and strength are influence only by microcracing.

\section{Acknowledgement}

This work was partially supported by the MSMT CR (contract No J304-098:210000020).

\section{References}

[1] Taylor H. F. W.: Cement Chemistry. London: Thomas Telford Publ., 1997.
[2] Odler I., Rossler M.: "Investigations on the Relationship between Porosity, Structure and Strength of Hydrated Portland Cement Pastes I a II." Cem. Concrete Res., Vol. 15 (1985), p. 320-330, 401-410.

[3] Jambor J.: "Influence of Phase Composition of Hardened Binder Pastes on its Pore Structure and Porosity." In: Pore Structure and Properties of Materials (Editor: S. Modrý). Prague: Academia, 1973, p. D75-D95.

[4] Fagerlund G.: Strength and Porosity of Concrete. In: Pore Structure and Properties of Materials (Editor: S. Modrý). Prague: Academia, 1973, p. D57-D73.

[5] Vydra V., Vodák F., Kapičková O., Hošková Š.: "Effect of Temperature on Porosity of Concrete for Nuklear-safety Structures.” Cem. Concr. Res., Vol. 301 (2001), p. 1023-1026.

[6] Vodák F. et al: "Tables of Physical Properties of Concretes for Nuclear-safety Structures." In: CTU Reports 4 (2000) (Editor: F.Vodák). Prague: CTU Publ. House, 2000.

[7] Bažant Z. P., Kaplan M. F.: Concrete at High Temperatures. Essex: Longman, 1996.

[8] Jambor J.: "Porosity, Pore Structure and Strength of Cementeous Composites.” Staveb. čas., Vol. 33 (1985), p. 743-764.

[9] Komarovskij A. N.: Design of Nuclear Plants. Moscow: Atomizdat, 1965.

[10] Hošková Š., Kapičková O., Trtík K., Vodák F.: Experimental study of relation among elevated temperature exposure, strength and structure of concrete employed in contaiment of NPP Temelin. In: Research activities of Physical Departments of Civil Engineering Faculties in the Czech and Slovak Republics. (Eds: L. Pazdera and M. Kořenská). Brno, 2001, p. 25-28.

[11] Zadražil T., Vodák F., Trtík K.: "Vliv teploty na pevnost betonu užitého při stavbě kontejnmentu jaderné elektrárny Temelín.” Stavební obzor, Vol. 9 (2003), p. 272-274.

Ing. Tomáš Zadražil

phone: +420224354693

e-mail: xzadrazt@stu.fsv.cvut.cz

Prof. František Vodák, DrSc.

phone: +420224353886

e-mail:vodak@fsv.cvut.cz

RNDr. Olga Kapičková, CSc.

phone: +420224354696

e-mail: kapickov@fsv.cvut.cz

Department of Physic

Czech Technical University in Prague

Faculty of Civil Engineering

Thákurova 7

16629 Praha 6, Czech Republic 